\title{
INCIDENCE OF YERSINIA IN RAW MILK AND KAREISH CHEESE WITH SPECIAL REFERENCE TO YERSINIA ENTERCOLITICA
}

\author{
Sohair, R. Basyoni ${ }^{a}$ and Nabila, l. Elsheikh ${ }^{b}$ \\ a; Provincial Marsa Matrooh Laboratory - b; Provencial Tanta Laboratory \\ Animal Health Research institute, Egypt.
}

\begin{abstract}
A Total of sixty random samples of raw milk and kareish cheese (30 of each) were collected randomely from various markets in Gharbia governorate for detection of Yersinia organisms.

The obtained results revealed that Yersinia species were isolated from $23.33 \%$ and $16.67 \%$ of the examined raw milk and kareish cheese samples respectively, Yersinia enterocolitica also isolated from $2(6.67 \%)$ and 3(10\%) samples of raw milk and kareish cheese respectively.
\end{abstract}

Furthermore, the isolated strains of Yersinia enterocolitica were sensitive to streptomycin, sulphamethoxazole, gentamycin, , danox and enrofloxacin, while they were resistant to pencillin, ampicillin and cefatoxine.

Public heath significance and possible sources of contamination of milk and its products with such organisms as well as some recommendations to ensure maximum margin of human safety were discussed.

\section{INTRODUCTION}

Yersinia may contaminate milk and milk products during processing, distribution and marketing as well as storage (Donnelly, 1990 and Pritchard et al., 1995).

Raw milk may play an important role for Yersiniosis in human being if it is consumed without sufficient heat treatment and / or used for 
manufacture of raw dairy products (Jayarao and Henning., 2001). Yersinia species can grow in a food item at refrigeration temperature (Psychrotrophic microorganisms) resultting in food borne outbreaks (Kirov et al., 1993) and destroyed by high temperature short time pasteurization condition of $71.8{ }^{\circ} \mathrm{C}$ for 18 seconds easily kill Yersinia enterocolitica (Tacket et al., 1984 , Schiemann,1989 and Padilha et al., 2001).

Kareish cheese is a raw milk product which manufactured by farmers at home from naturally fermented milk by lactic acid bactria, this method may expose the product to contamination with certain Yersinia species constituting public health hazard (Hamama et al., 1992).

Therefore, the aim of the present study was planned to determine the incidence of Yersinia species in raw milk and kareish cheese and to study the effect of lowering $\mathrm{pH}$ (acidity) on viability of Yersinia enterocolitica in raw milk kept at room temperature .

\section{MATERIALS AND METHODS}

\section{1- a. Sampling :}

Sixty random samples of raw milk and Kareish cheese (30 each) were collected from street vendors in Ghariba governorate. The collected samples were transferred to the laboratory in sterile bags without delay for detection of Yersinia microorganisms

\section{b. Preparation of samples:}

All milk samples were tested by peroxidase test to exclude heattreated milk samples.Then, $25 \mathrm{ml}$ of raw milk or $25 \mathrm{gm}$ of kareish cheese were thoroughly mixed with $225 \mathrm{ml}$ Trypticase Soya Broth (TSB), flasks were incubated at $22^{\circ} \mathrm{C}$ for 24 hours (Schiemann, 1983). One $\mathrm{ml}$ from each of the pre-enrichment broth was added to $9 \mathrm{ml}$ of sterile PeptonSorbitol-Bile(PSB) broth supplemented with Novobiocin $(10 \mu \mathrm{g} / \mathrm{ml})$ and Polymexin (5 I.U./ml) and incubated at $22^{\circ} \mathrm{C}$ for $48-72$ hours (Landgraf et al., 1993). 


\section{c. Isolation and identification of yersinia:}

A loopful from each PSB broth was streaked on to CefsulodinIrgasan-Novobiocin (CIN) agar plate and incubated at $30{ }^{\circ} \mathrm{C}$ for $18-20$ hours. Characteristic colonies (dark red center, with transparent border) were picked up and subcultured onto slope nutrient agar for further identification according to Seelinger and Jones (1986).

\section{2- Experimental study in raw milk:}

Yersinia enterocolitica isolated culture was maintained on Trypticas Soya Agar (TSA) at $4{ }^{\circ} \mathrm{C}$. then acolony of Yersinia enterocolitica was picked and grown on Trypticase Soya Broth( TSB )at $30{ }^{\circ} \mathrm{C}$ overnight. One $\mathrm{ml}$ of the culture was serially diluted in $0.1 \%$ pepton water to attain the desired inoculum level and then added to raw milk to yeild a concent-ration of $2.5 \times 10^{7}$ C.F.U/ml . The inoculated milk was incubated at $30^{\circ} \mathrm{C}$ and examined after $6,12,18,24,30$ and 36 hours. Ten $\mathrm{ml}$ of the milk sample was added to $90 \mathrm{ml}$ of $0.1 \%$ sterile peptone and , $100 \mu 1$., was inoculated onto Cefsulodin - Irgasan Novobiocin agar. The plates were incubated at $30^{\circ} \mathrm{C}$ for 48 hours and countable plates were selected and counted.

\section{3- Determination of pH:}

The $\mathrm{pH}$ of inoculated milk was determined by using $\mathrm{pH}$-meter model (HANNA, HI 8014).

\section{4- Antibiotic susceptibility test:}

The isolated strains of Yersinia enterocolitica were tested against Streptomycin $10 \mu \mathrm{g}$, Enrofloxacin $10 \mu \mathrm{g}$, gentamycin GM, Ampicillin $10 \mu \mathrm{g}$, Sulphamethoxzole $25 \mu \mathrm{g}$, danox $5 \mu \mathrm{g}$,cefataxine $30 \mu \mathrm{g}$ and pencillin $\mathrm{G} 10 \mu \mathrm{g}$. The antibiotic discs were placed on the surface of Trypticas soya agar plate and incubated overnight at $37^{\circ} \mathrm{C}$, the diameter of inhibition zone of Yersinia enterocoltica were measured and interpreted by referring tables recommended by National Committee for Clinical Laboratory Standards (NCCLS) (Finegold and Martin, 1982). 


\section{RESULTS}

Table (1): Incidence of Yersinia spp.in examined samples of raw milk and kareish cheese. (No. 30).

\begin{tabular}{|c|c|c|c|c|}
\hline \multirow{3}{*}{ Yersinia spp } & \multicolumn{2}{|c|}{ Raw milk } & \multicolumn{2}{|c|}{ Kareish cheese } \\
\hline & \multicolumn{2}{|c|}{ Positive samples } & \multicolumn{2}{|c|}{ Positive samples } \\
\hline & No. & $\%$ & No. & $\%$ \\
\hline Y.enterocolitica & 2 & 6.67 & 3 & 10.00 \\
\hline Y. Pestis & 4 & 13.33 & 1 & 3.33 \\
\hline Y.pseudotuberculosis & 1 & 3.33 & 1 & 3.33 \\
\hline Total & 7 & 23.33 & 5 & 16.67 \\
\hline
\end{tabular}

Table (2): viability of isolated Yersinia enterocolitica in raw milk kept at room temperature.

\begin{tabular}{|c||c|c|c|}
\hline Time & PH & Count & Multiplication or reduction \% \\
\hline \hline Zero time & 6.8 & $2.5 \times 10^{7}$ & - \\
\hline 6 hours & 6.7 & $4.0 \times 10^{7}$ & 60 \\
\hline 12 hours & 6.6 & $3.0 \times 10^{7}$ & 20 \\
\hline 18 hours & 6.5 & $2.6 \times 10^{7}$ & 4 \\
\hline 24 hours & 5.5 & $1.2 \times 10^{7}$ & -52 \\
\hline 30 hours & 5.2 & $8.0 \times 10^{6}$ & -68 \\
\hline 36 house & 4.5 & $5.0 \times 10^{6}$ & -80 \\
\hline
\end{tabular}


Incidence Of Yersinia In Raw Milk And Kareish ...

Table (3): Antibiotic sensitivity test for the isolated strains of Yersinia entericolitica

\begin{tabular}{|c|c|c|c|}
\hline Antibiotic discs in $\mu \mathrm{g}$. & Sensitive & Inter-Mediate & Resistant \\
\hline Penicillin G (10) & - ve & -ve & + ve \\
\hline Enrofloxacin EN (10) & $+\mathrm{ve}$ & $-\mathrm{ve}$ & -ve \\
\hline Danox DNF (5) & $+\mathrm{ve}$ & - ve & -ve \\
\hline Gentamycin GM & $+\mathrm{ve}$ & - ve & -ve \\
\hline Ampicillin Amp (10) & -ve & $+\mathrm{ve}$ & -ve \\
\hline Cefataxine ctx (30) & -ve & $+\mathrm{ve}$ & -ve \\
\hline Sulphamethoxazole (25) & $+\mathrm{ve}$ & -ve & -ve \\
\hline Streptomycin S (10) & $+\mathrm{ve}$ & -ve & -ve \\
\hline
\end{tabular}

Table (4): Incidence of compitative microorganisms like Yersinia spp. grown on CIN agar.

\begin{tabular}{|c||c|c||c|c||}
\hline \multirow{2}{*}{\multicolumn{1}{|c||}{ Compitator organisms }} & \multicolumn{2}{c||}{ Raw milk } & \multicolumn{2}{c|}{ Kareish cheese } \\
\cline { 2 - 5 } & Positive & Samples & Positive & Samples \\
\cline { 2 - 5 } & No. & $\%$ & No. & $\%$ \\
\hline \hline Proteus species & 4 & 13.33 & 1 & 3.33 \\
\hline P. mirabilis & 1 & 3.33 & - & - \\
\hline P. rettgeri & 1 & 3.33 & - & - \\
\hline P. vulgaris & 2 & 6.67 & 1 & 3.33 \\
\hline Providencia alcalifaciens & 2 & 6.67 & - & - \\
\hline Pseudomonas fluorescens & 3 & 10 & 1 & 3.33 \\
\hline Serratia rubidanea & 1 & 3.33 & - & - \\
\hline
\end{tabular}

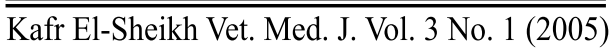




\section{DISSCUSSION}

The results outlined in table (1) indicate that the incidence of Yersinia species in examied samples of raw milk and kareish cheese was $23.33 \%$ and $16.67 \%$, from which $6.67 \%$ and $10 \%$ were identified as Yersinia enterocolitica, $13.33 \%$ and $3.33 \%$ as Yersinia pestis and $3.33 \%$ and $3.33 \%$ as Yersinia pseudotuberculosis, respectively.

Nearly similar findings were reported by Karplyk et al., (1985) who detected Yersinia enterocolitica in $0.2 \%$ of raw milk samples, while higher percentages were obtained by Franzin et al., (1984), Mmoh et al., (1984) and El-Sherbini et al., (1993). Yersinia organisms are widely distributed in nature and a variety of food including milk and milk products. Most food isolates were non pathogenic and known as environ mental strains (Adams and Moss, 1995).

Table (2) show that the effect of natural acidity on the survival of Yersinia enterocolitica in raw milk. The number increased from $2.5 \times 10^{7}$ to $4.0 \times 10^{7}$ C.F. U/ml after 6 hours, then decreased gradually over a period of $12-36$ hours tell reached to $5.0 \times 10^{6}$ C.F.U / $\mathrm{ml}$ after 36 hours when the raw milk completely fermented and the $\mathrm{pH}$ measured 4.5 . These finding agree with karaioannoglou et al., (1985) who reported that Yersinia enterocolitica can grow and multiply at $\mathrm{pH} 5.3-5.5$ over a period of 30 days.

Table (3) reveal that the isolated strain of Yersinia enterocolitica was sensitive to streptomycin, sulphamethoxazole, Gentamycin, danox and enrofloxacin, while resistant to pencillin and varied in susceptibility to ampicilline \& cefataxine. Henin and Kaldas (1995) reported that, the isolated strains of Yersinia enterocolitica were highly sensitive to gentamycin, neomycin, nalidixic acid and amikacin. Moreover, Abdel-Khalek (1998) reported that, the isolated strains of Yersinia enterocolitica were sensitive to gentamycin and chloramphenical, resistent to pencillin, while varied in susceplibility to erythromycin \& Neomycin . 
Inspection of table (4) reveal that high incidence of compitative microorganismes that have the same morphological characters on CIN agar as Yersinia organisms, those bacteria were Proteus spp., Providencia alcalifaciens, Pseudomonas fluorescens and Serratia rubidanee. The obtained results were similar to that obtained by Walker, (1989a) and El-Sherbini (1990). Psychrotrophs can produce extracellular thermostable proteolytic and lipolytic enzymes which responsible for off flavor and yield loss in cheese manfacture. (Prieto et al., 2002).

Yersinia enterocolitica is an enteric pathogen of emerging importance. It causes illness characterized by gastrointestinal disorder, pseudo appendicular syndrom, arthritis, erythema nodsum and septicemia which cause death (Morse et al., 1984 ; Tacket et al, 1984 and IDF , 1994). Accordingly, the present results allow to conclude that consumption of raw milk and milk products cotaminated with Yersinia enterocolitica has a potential health hazard. Utilization of pasteurized milk in manufacturing of milk products is safe and free from contamination is of great significance to avoid such serious organisms to gain access in these milk products. Also proper cleaning and sanitation of dairy equipments where Yersinia is more susceptible to chlorine than other enteric bacteria with concentration of $0.25 \mathrm{ppm}$ chlorine dioxide for $5 \mathrm{~min}$, that can reduce Yersinia by 4 to $5 \log$ cycles.

\section{REFERENCE}

- Abdel Khalek, A. (1998): The incidence of Y.enterocolitica in dairy foods. Vet. Med. J., 46 (4B) : 629-634.

- Adams, M.R. and Moss, M.O. (1995): Food microbiology. The Royal Society of Chemistry, Cambridge

- Donnelly, C.W. (1990): Concerns of microbial pathogens in association with dairy foods. J.Dairy Sci, $73: 1656-1661$.

- El-Sherbini, M. (1990): Occurrence and behavior of pathogenic microorga-nisms especially Listeria monocytogens in milk and some dairy products. Ph D. Thesis fac Vet. Med. Zag. Univ.

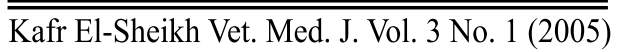


- El-Sherbini, M.; El-Laboudy, A.A. and El-Sayed, M.S. (1993): Fate of Y. enterocolitica in kareish cheese. J Egyptian Vet. Med. Association 53 (1):145-151.

- Finegold, S.M. and Martine, W.T. (1982): Diagnostic microbiology $6^{\text {th }}$ ed. C.V. mobsy Campany, U.S.A.

- Frazin, L.; Fantiona, P. an dViolotto, V. (1984): Isolation of Y.enterocoli-tica and Y.enterocolitica like organisms from raw milk in Italy Current Microbiology 10 (6) : 357-360.

- Hamama, A; El Marrakchi, A.and El Othmani, F. (1992): Occurrence of Y.enterocolitica in milk \& dairy products in Morocco. Int. J. Food .Microbi-ology, May,16 (1) : 69-77.

- Henin, A.Y. and Kaldas, Y.T.: Prevalence and characterization of Y. enterocolitica isolated from raw milk and ice-cream in Minia city, Egypt. J. Egyptian Vet. Med. Ass., 55 (1\&2):59-66.

- International Dairy Federation (IDF). (1994): The significance of pathog-enic microorganisms in raw milk . 41 square vergote, B 1090 Brussels (Belgium).

- Jayarao, B.M and Henning, D.R. (2001): Prevalence of food borne patho-gens in bulk tank milk J. Dairy Sci., 84 (10) : 2157-62.

- Karaioannoglou, L.; Koidis, L. and Mantis, A. (1985): Survival of Y. enterocolitica during the manufacture and storage of Feta cheese. Milchwis-sneschaft,40 (4): 204.

- Karplyuk, I. A.; Yushchenko, G.V.; Dogel, L.D.; Salova, N.Y. and Kashintseva, I.A. (1985): Contamination of milk and milk products with Y.enterocolitca during handling and processing. Voprosy pitaniya $6: 57-59$. Dairy sci. Abst. , 50 (3) : 125.

- Kirov, M.S.;Hui, S.D. and Hayward, L.J. (1993): Milk as potential source of Aeromonas gastrointestinal infection. J. food protection, $56: 306-312$. 
- Landgrof,M.;Iaria,S.T and Falcao, D.P. (1993): An improved enrichment procedure for isolation of Y.enterocolitica and related species from milk. J. food protection, 56 (5) : 447-450.

- Morse, D.L. ; Shayengani, M. and Gallo, R.J.(1984): Epidemiological investigation of yersinia camp. outbreak linked to a food handler. American J. public health, 74 : 589-592.

- Padilha,M.R; Fernandes, Z.F;, Leal, T.C; Leal, N.C and Almeida, A.M. (2001): Isolation of bacteria in pasteurized type $C$ Milk sold in Recife city, pernambuco, Brazil. Rev. Soc. Bras., Med Trop. MarApr;34 (2) : 167-71.

- Prieto, B.; Franco, I. And Bernardo, A. (2002): Proteolytic \& lipolytic changes during the ripening of lean raw cow's milk cheese, a Spanish tradit-ional variety. Int. J. food Sci, Technol. 37,661-671.

- Pritchard,T.J.;Beliveau,C.M.;Flanders,K.J. and Donnelly, C.W. (1995): Environmental surveillance of dairy processing plant for the presence of yersinia species J. food protection, 58 (4) : 395-397.

- Schiemann, D.A. (1983): Comparison of enrichment and plating media for recovery of virulent strains of Y.enterocolitica form inoculated beef stew. J. Food Protection, 46 : 957-964.

- Schiemann, D.A. (1989): Y. enterocolitica and Y. pseudotuberclosis in foodborne bacterial pathogens. Ed. Michael . P. Doyle, PP. 601671. Marcel Decker INC. New York \& Barasil .

- Seelinger, H.P.R. and Jonos, D. (1986): In Bergey's Manual of Systemic Bacteriology, 2Eds. Seneath, P.A.A.; Seneath, N.; Mair, N.S.; Sharp, M.E. and Holt, J.G., 1235-1245.

- Tacket, C.O.; Narain, J.P.; Sattin, R.; Lofgren, J.P.; Kongisberg, C.; Rendtroff, Jr. R.C.; Rausa, A.; Davis, B.R. and Cohen, M.L. (1984): A multi state outbreak of infection caused by $Y$. enterocolitica transmitied by pasteurized milk. Jama J.American Medical Associations, 251 (4) : 483-486.

$\overline{\text { Kafr El-Sheikh Vet. Med. J. Vol. } 3 \text { No. } 1 \text { (2005) }}$ 
- Umoh, V.J.; Dangan, A. and Umoh, J. U. (1984): Isolation of Y. enteroco-litica from milk products in Zaria,Nigeria. International $\mathrm{J}$. Zoon.,11:223-228.

- Varnama, A.H. and Evans, M.G. (1991): Food borne pathogen. Wolfe Publish ltd. B.P.C.C. Hazell Books, Aylesbury, England.

- Walker, S.J. (1989a): Yersinia. In Advanced Food Microbiology Course Surrey University. Department of Microbiology. Campden Food and Drink Research Association. Chipping Compden, Glos.GL556LD. 
مدي تو اجد ميكروب اليرسينيا في اللبن الخام و الجبن القريش في محافظة الغربية

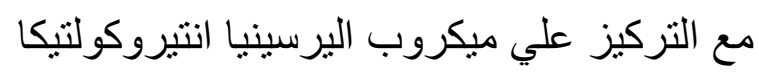

د/سهير رشاد بسيوني - د/ نبيلة إبراهيم عبد السلام الشيخ

$$
\text { المعمل الفرعي بمرسي مطروح - المعل الفرعي بطنطا }
$$

\section{معهد بحوث صحة الحيوان}

تتعرض الا لبان ومنتجاتها للتلوث بمختلف أنواع الميكروبات التى منها ما يسبب الفساد ومنها ما يمثل خطورة صحية على المستهلك.

لذلك قامت هذه الدراسة على جمع عدد ستين عينة (60) من اللبن الخام والجبن القريش (30 من كل نوع ) من الاسواق المختلفة بمحافظة الغربية وذلك لتحديد مدى تلوثها بميكروبات اليرسينيا.

وقد دلت الدراسة على تواجد ميكروبات اليرسينيا بنسبة 23.33\% ، 16.67 \% ، وكانت

العترات المعزولة هى يرسينيا انتيروكوليتكا (6.67\%،10\%) يرسينيا بسنس (13.33 \% ،3.33\%) ويرسينيا سيدوتيوبركلوزس (33.33\%33.33\%) من عينات اللبن الخام و الجبن القريش على التوالي.

هذا وقد نم إجراء اختبار الحساسية لمعرفة مدى تأثير المضادات الحيوية على ميكروب اليرسينيا انتيروكوليتكا ، وقد وجد ان هذا الميكروب حساس لكل من الانروفلوكساسين والدانوكس والجنتاميسين والكلورمفينيكول والسلفاميسوكال والستربتوميسين ، وعلى العكس فإن كل من البنسلين والامبسلين والسيفاتكسين كان تأثثرها ضعيفا على الميكروب.

وقد اهتمت الدراسة بمناقثة الأهية الصحية لميكروبات اليرسينيا و المصادر المحتملة لتلوث

الألبان ومنتجاتها بهذه الميكروبات،وتم وضع بعض التوصيات لحماية المستهلك من تلك الميكروبات.

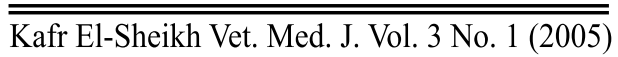

